\title{
Pancreatic Acinar Cell Neoplasm
}

National Cancer Institute

\section{Source}

National Cancer Institute. Pancreatic Acinar Cell Neoplasm. NCI Thesaurus. Code C95542.

An epithelial neoplasm that arises from the exocrine pancreas. It is characterized by the presence of neoplastic cells that resemble acinar cells and produce pancreatic exocrine enzymes. The vast majority are carcinomas. 